\title{
Mechanism of action of coumarin and silver(I)-coumarin complexes against the pathogenic yeast Candida albicans
}

\author{
Bhumika Thati ${ }^{a, b}$, Andy Noble ${ }^{\text {b }}$, Raymond Rowan ${ }^{\text {a,c }}$, Bernadette S. Creaven ${ }^{\text {b }}$, \\ Maureen Walsh b, Malachy McCann c , Denise Egan ${ }^{\text {b }}$, Kevin Kavanagh ${ }^{\text {a,* }}$ \\ a Medical Mycology Unit, National Institute for Cellular Biotechnology, Department of Biology, National University of Ireland Maynooth, \\ Co. Kildare, Ireland \\ ${ }^{\mathrm{b}}$ Pharma R\&D Team, Institute of Technology Tallaght, Dublin 24, Ireland \\ ${ }^{\mathrm{c}}$ Department of Chemistry, National University of Ireland Maynooth, Co. Kildare, Ireland
}

Received 2 June 2006; accepted 29 January 2007

\section{Abstract}

The anti-fungal activity and mode of action of a range of silver(I)-coumarin complexes was examined. The most potent silver(I)-coumarin complexes, namely 7-hydroxycoumarin-3-carboxylatosilver(I), 6-hydroxycoumarin-3-carboxylatosilver(I) and 4-oxy-3-nitrocoumarinbis(1,10-phenanthroline)silver(I), had $\mathrm{MIC}_{80}$ values of between 69.1 and $4.6 \mu \mathrm{M}$ against the pathogenic yeast Candida albicans. These compounds also reduced respiration, lowered the ergosterol content of cells and increased the trans-membrane leakage of amino acids. A number of the complexes disrupted cytochrome synthesis in the cell and induced the appearance of morphological features consistent with cell death by apoptosis. These compounds appear to act by disrupting the synthesis of cytochromes which directly affects the cell's ability to respire. A reduction in respiration leads to a depletion in ergosterol biosynthesis and a consequent disruption of the integrity of the cell membrane. Disruption of cytochrome biosynthesis may induce the onset of apoptosis which has been shown previously to be triggered by alteration in the location of cytochrome $c$. Silver(I)-coumarin complexes demonstrate good anti-fungal activity and manifest a mode of action distinct to that of the conventional azole and polyene drugs thus raising the possibility of their use when resistance to conventional drug has emerged or in combination with such drugs.

(C) 2007 Published by Elsevier Ltd.

Keywords: Anti-fungal; Candida albicans; Coumarin; Phenanthroline; Silver(I); Yeast

\section{Introduction}

Coumarin is a a benzopyrone and a naturally occurring constituent of many plants and essential oils, including tonka beans, sweet clover, woodruff, oil of cassia and lavender. Antibiotics containing the coumarin nucleus, such as novobiocin, clorobiocin, and coumermycin $\mathrm{A}_{1}$ produced by a number of the Streptomyces species, were identified over forty years ago. The use of these antibiotics has been limited due to their poor water solubility, low activity against

\footnotetext{
* Corresponding author. Tel.: +3531708 3859; fax: +35317083845.

E-mail address: kevin.kavanagh@NUIM.ie (K. Kavanagh).
}

Gram-negative bacteria and the rapid emergence of resistance (Lewis et al., 1996; Laurin et al., 1999). However, renewed interest in these antibiotics has arisen following the discovery that they are potent catalytic inhibitors of DNA gyrase. Additionally, these antibiotics have been shown to be active against Gram-positive bacteria, especially against methicillin-resistant Staphylococcus aureus (MRSA) (Laurin et al., 1999). Further derivatisation of novobiocin, clorobiocin, and coumermycin $A_{1}$ has allowed for the production of novel coumarin antibiotics displaying excellent inhibition of DNA supercoiling by DNA gyrase B and good antibacterial activity against vancomycin, teicoplanin and novobiocin resistant Enterococci species (Laurin et al., 1999). 
Candida albicans is pathogenic yeast which is consistently the most frequently isolated etiological agent of candidosis in humans (Coleman et al., 1998). Candidosis is the commonest invasive fungal infection in patients with malignant haematological disease and in bone marrow transplant recipients (Warnock, 1998). Nosocomial infections due to opportunistic fungal pathogens are a common cause of mortality among hospitalised patients (Micheal, 1995). The development of azole-based anti-fungal drugs has revolutionized the treatment of many fungal infections, but therapy may still necessitate application of the highly toxic drug amphotericin B or a combination of drugs.

Plant extracts containing coumarin derivatives demonstrate anti-fungal activity (Tiew et al., 2003) and some synthetic coumarin derivatives are also active against the yeast C. albicans (Zaha and Hazem, 2002). The presence of phenolic, hydroxy and carboxylic acid groups on the coumarin nucleus has been considered necessary for antimicrobial activity (Kawase et al., 2001). Coumarin derivatives are able to coordinate a transition metal ion via the oxygen of the carbonyl group on the lactone ring (Irena et al., 2001) which raises the possibility that coordinating metals to coumarin may potentiate its anti-microbial toxicity.

The aim of the work presented here was to investigate the anti-fungal activity of some coumarin derivatives and also the silver(I) complexes of these derivatives.

\section{Materials and methods}

\subsection{Culture conditions}

C. albicans ATCC 10231 (obtained from the American Type Culture Collection, Maryland, USA) was maintained on YEPD agar [ $2 \%(\mathrm{w} / \mathrm{v})$ glucose (Sigma-Aldrich Chemical Co Ltd. Dublin, Ireland), 2\% (w/v) bactopeptone (Difco Laboratories, Detroit, USA), $1 \%$ (w/v) yeast extract (Oxoid Ltd., Basingstoke, England), 2\% (w/v) agar] plates, sub-cultured every 6-8 weeks and stored at $4{ }^{\circ} \mathrm{C}$. Fresh cultures were grown at $30^{\circ} \mathrm{C}$ in YEPD broth (as above but without agar). All cultures were grown to the stationary phase (approximately $1 \times 10^{8}$ cells $/ \mathrm{ml}$ ) overnight in $50 \mathrm{ml}$ Antibiotic Medium 3 (Oxoid Ltd.) broth at $30^{\circ} \mathrm{C}$ and $200 \mathrm{rpm}$.

\subsection{Synthesis of coumarin derivatives}

Coumarin-3-carboxylic acid (CcaH), 4-hydroxy-3-nitrocoumarin $(\mathrm{hncH})$ and 7-hydroxy-4-methyl-8-nitrocoumarin (hmnc), were purchased from Sigma-Aldrich Co. (Dorset, UK) and used without further purification. The synthesis of the ligands, 6-hydroxycoumarin-3-carboxylic acid (6-OHC$\mathrm{caH})$, 7-hydroxycoumarin-3-carboxylic acid (7-OHCcaH), 8-hydroxycoumarin-3-carboxylic acid (8-OHCcaH), and the silver(I) complexes, coumarin-3-carboxylatosilver(I) $[\mathrm{Ag}(\mathrm{Cca})]$, 6-hydroxycoumarin-3-carboxylatosilver(I) [Ag(6-OHCca)], 7-hydroxycoumarin-3-carboxylatosilver(I) [Ag(7-OHCca)], and 8-hydroxycoumarin-3-carboxylatosilver(I) $[\mathrm{Ag}(8-\mathrm{OHCca})]$, have been described previously (Cre-

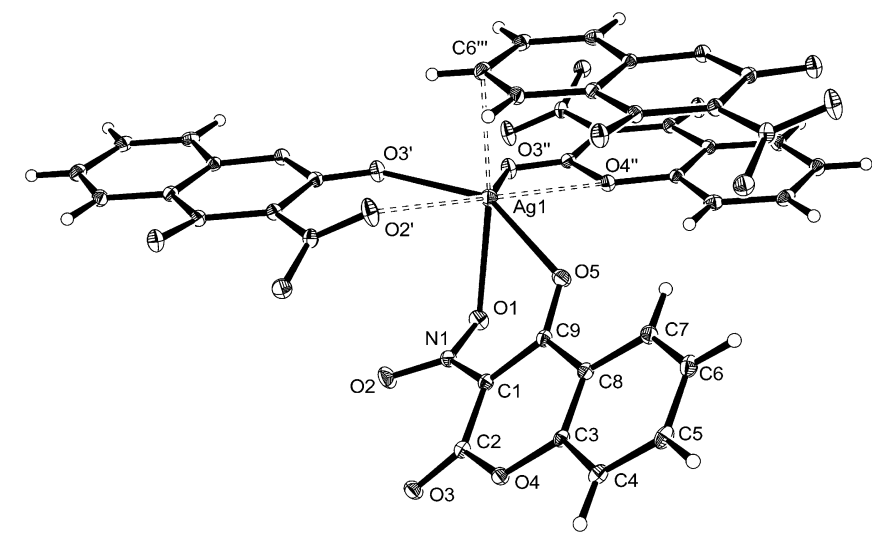

Fig. 1. Crystal structure for $\left[\operatorname{Ag}(\mathrm{phen})_{2}(\mathrm{hnc})\right]$.

aven et al., 2006). The synthesis of the silver(I) complexes of $\mathrm{hncH}$ and $\mathrm{hmncH}$, namely 4-oxy-3-nitrocoumarinsilver(I) [Ag(hnc)] and 4-methyl-8-nitro-7-oxycoumain silver(I) $[\mathrm{Ag}(\mathrm{hmnc})]$ togetehr with the 1,10-phenanthroline (phen) complex, 4-oxy-3-nitrocoumarinbis(1,10-phenanthroline) silver(I) $\left[\mathrm{Ag}(\mathrm{phen})_{2}(\mathrm{hnc})\right]$ have been described (Creaven et al., 2005). The crystal structure of $\left[\mathrm{Ag}(\mathrm{phen})_{2}(\mathrm{hnc})\right]$ is displayed in Fig. 1. The structure of all other complexes and ligands are displayed in (Creaven et al., 2005 and 2006).

\subsection{Anti-fungal susceptibility test}

Yeast cells were grown overnight to the stationary phase in $50 \mathrm{ml}$ Antibiotic Medium 3 (Oxoid) at $30^{\circ} \mathrm{C}$ and $200 \mathrm{rpm}$. Cell density was determined using an haemocytometer and adjusted to $1 \times 10^{6}$ cells $/ \mathrm{ml}$, by dilution with Antibiotic Medium 3. Cells were added to each well of a 96well plate containing the test compound, diluted in medium using serial dilutions from 100 to $0.25 \mu \mathrm{g} / \mathrm{ml}$. Plates were incubated at $30^{\circ} \mathrm{C}$ for $24 \mathrm{~h}$, and the optical density (OD) was determined at $450 \mathrm{~nm}$ using a MRX spectrophotometer (Dynex Technology). $\mathrm{MIC}_{80}$ was determined to be the lowest concentration of drug required to reduce cell growth by $80 \%$ relative to the control.

\subsection{Measurement of oxygen uptake}

Stationary phase cells (approximately $1.5 \times 10^{8}$ cells $/ \mathrm{ml}$ ) grown in YEPD broth at $30^{\circ} \mathrm{C}$ overnight were harvested, washed with $0.025 \mathrm{M}$ phosphate buffered saline (PBS, pH 7.2) and resuspended in $0.025 \mathrm{M}$ phosphate buffer $(\mathrm{pH} 7.2)$ at a cell density of $5 \times 10^{8} / \mathrm{ml}$. Oxygen uptake measurements were made at $30^{\circ} \mathrm{C}$ using a Clark-type oxygen electrode. Oxygen uptake rates were calculated as $\mu$ moles of oxygen consumed $/ 60 \mathrm{~s} / 10^{8}$ cells.

\subsection{Cytochrome analysis}

Yeast cultures were supplemented with specific concentrations of each drug and incubated for $18-24 \mathrm{~h}$ at $30^{\circ} \mathrm{C}$. Cells $\left(2 \times 10^{10}\right)$ were harvested by centrifugation at $3000 \mathrm{~g}$ for $5 \mathrm{~min}$, washed twice with PBS and divided into two
122 
equal volumes. One half of the sample was oxidised by suspending in $0.2 \%(\mathrm{w} / \mathrm{v})$ sodium hypochlorite solution followed by harvesting by centrifugation and then resuspended in $50 \%(\mathrm{v} / \mathrm{v})$ glycerol. The remaining half sample was resuspended in $50 \%(\mathrm{v} / \mathrm{v})$ glycerol and reduced by adding a few crystals of sodium-dithionate. The reduced and oxidised cytochrome differential spectrum was immediately recorded using a double beam UV-Visible spectrophotometer at 500-650 nm (Cary IE Varian).

\subsection{Sterol extraction and quantification}

Yeast cells were grown in the presence of half $\mathrm{MIC}_{80}$ of test agent until cells reached the late exponential phase (approximately $1 \times 10^{7} / \mathrm{ml}$, and typically for $18-24 \mathrm{~h}$ ) in Antibiotic Medium 3 at $30^{\circ} \mathrm{C}$ in an orbital incubator. Yeast cells $\left(2 \times 10^{9}\right.$ cells $)$ were harvested and washed with PBS. Cells were resuspended in $1.5 \mathrm{ml}$ of a solution containing $20 \%(\mathrm{w} / \mathrm{v})$ potassium hydroxide and $60 \%(\mathrm{v} / \mathrm{v})$ ethanol and placed in a shaking water bath at $90^{\circ} \mathrm{C}$ for $1.5-2 \mathrm{~h}$. Heptane was added to this solution and vortexed for $10 \mathrm{~s}$. The upper layer containing sterols was removed according to the method of Arthington-Skaggs et al. (2000).

Sterol analysis was determined by using a double beam UV-Visible spectrophotometer (Cary IE Varian) over the range $240-320 \mathrm{~nm}$. An ergosterol standard curve was constructed over the range $100-0.25 \mu \mathrm{g} / \mathrm{ml}$. Sterol concentrations were also determined using a gas chromatographic system (Hewlett Packard 5890, Series 11) with a flame ionisation detector and a Chromopack capillary column (Chromopack International BV, Middleburg, The Netherlands) operated isothermally at $300^{\circ} \mathrm{C}$. Injector and detector temperatures were $320^{\circ} \mathrm{C}$ and the carrier gas was $\mathrm{N}_{2}$.

\subsection{Evaluation of membrane leakage}

Stationary phase cells $\left(1 \times 10^{10}\right.$ in total $)$ were harvested by centrifugation, washed with PBS and resuspended in $10 \mathrm{ml}$ PBS. Test agents were added to this suspension at a final concentration of half $\mathrm{MIC}_{80}$. Samples of cell suspension were recovered after $4 \mathrm{~h}$ and assayed for the presence of amino acids using the ninhydrin method (Reeves et al., 2004). The filtrate was passed through a $0.45 \mu \mathrm{M}$ syringe filter (Sartorius, AG Goettingen, Germany) and free amino acid was measured as described. The amino acid concentration was expressed in terms of aspartic acid and glutamic acid which were used as standards. Ninhydrin (Sigma Aldrich) solution $(200 \mu \mathrm{l}$ of $0.35 \mathrm{~g} / 100 \mathrm{ml}$ ethanol) was added to each sample $(1 \mathrm{ml})$ and the mixture heated to $95^{\circ} \mathrm{C}$ for $4 \mathrm{~min}$. After cooling to room temperature in an ice bath, the OD at $570 \mathrm{~nm}$ was recorded on a UV-Visible spectrophotometer (Beckmann, DU 640).

\section{Electron microscopy}

Yeast cells were grown to the stationary phase in the presence of half-MIC $\mathrm{M}_{80}$ levels of each test agent. Primary fixation of yeast cells was carried out in a 3\% (v/v) solution of glutaraldehyde in $0.1 \mathrm{M}$ phosphate buffer for $2 \mathrm{~h}$. Secondary fixation was achieved in $0.2 \%(\mathrm{w} / \mathrm{v})$ osmium tetroxide in $0.1 \mathrm{M}$ phosphate buffer for $1 \mathrm{~h}$. Samples were dehydrated in graded alcohol solutions of 10, 30, 50, 75, 95, and $100 \%(\mathrm{v} / \mathrm{v})$ for $15 \mathrm{~min}$. Samples were embedded in Agar 100 resin (Agar Scientific Ltd., UK) and viewed with a Hitachi H-7000 transmission electron microscope operating at $100 \mathrm{kV}$ accelerating voltage.

\section{Extraction of DNA from C. albicans}

Yeast cells were grown in the presence of test agent at a concentration equivalent to half $\mathrm{MIC}_{80}$, in Antibiotic Medium 3 at $30^{\circ} \mathrm{C}$ and $200 \mathrm{rpm}$, using an orbital shaker. DNA was extracted from cells $\left(4 \times 10^{9}\right)$ as described earlier (Coyle et al., 2004). The integrity of extracted DNA was determined by agarose gel electrophoresis as described (Coyle et al., 2004). Samples were loaded onto an agarose gel and electrophoresed at $80 \mathrm{~V}$ for $1 \mathrm{~h}$. DNA bands were visualised by irradiation at $300 \mathrm{~nm}$ and photographed using a Pharmaciae 3D imaging system.

\section{Statistical analysis}

All experiments were performed on three independent occasions and results are the mean \pm SEM. Statistical analysis was performed using the non-parametric Mann-Whitney test at a $95 \%$ confidence interval.

\section{Results}

\subsection{Effects of coumarin derivatives on fungal cells}

A series of novel coumarin ligands and their silver(I) complexes (Table 1) were screened for their anti-fungal activity. The $\mathrm{MIC}_{80}$ of each compounds was determined over a concentration range of $500-0.25 \mu \mathrm{M}$. Results indicate that both the number and position of functional groups along with the presence of silver on the coumarin

Table 1

Anti-fungal activity of coumarin derivatives

\begin{tabular}{llr}
\hline Compound no. & Compounds screened & $\mathrm{MIC}_{80}(\mu \mathrm{M}) \pm \mathrm{SEM}$ \\
\hline 1 & $\mathrm{CcaH}$ & $332.00 \pm 1.75$ \\
2 & {$[\mathrm{Ag}(\mathrm{Cca})]$} & $163.40 \pm 2.44$ \\
3 & {$[\mathrm{Ag}(8-\mathrm{OHCca})]$} & $270.00 \pm 1.46$ \\
4 & {$[\mathrm{Ag}(7-\mathrm{OHCca})]$} & $69.30 \pm 0.95$ \\
5 & {$[\mathrm{Ag}(6-\mathrm{OH}-\mathrm{Cca})]$} & $34.10 \pm 0.58$ \\
6 & {$[\mathrm{Ag}(\mathrm{hmnc})]$} & $246.00 \pm 2.24$ \\
7 & {$[\mathrm{Ag}(\mathrm{hnc})]$} & $222.00 \pm 1.82$ \\
8 & {$\left[\mathrm{Ag}(\mathrm{phen})_{2}(\mathrm{hnc})\right]$} & $4.60 \pm 0.75$ \\
\hline
\end{tabular}

Anti-fungal activity of coumarin derivatives screened against $C$. albicans following continuous incubation in the presence of drug for $24 \mathrm{~h}$, using micro-dilution assay.

Results are mean of three independent experiments \pm SEM. All values were statistically different when compared to the control (compound 1) at $p<0.05$. 
nucleus, greatly affected the fungistatic capacity of the coumarin derivatives. This is evident from the $\mathrm{MIC}_{80}$ values presented in Table 1 and include: $[\mathrm{Ag}(8-\mathrm{OHCca})](270 \mu \mathrm{M})$, $[\mathrm{Ag}(\mathrm{hmnc})] \quad(246 \mu \mathrm{M}), \quad[\mathrm{Ag}(\mathrm{hnc})] \quad(222 \mu \mathrm{M}), \quad[\mathrm{Ag}(\mathrm{Cca})]$ $(163 \mu \mathrm{M}),[\mathrm{Ag}(7-\mathrm{OHCca})](69.30 \mu \mathrm{M})$ and $[\mathrm{Ag}(6-\mathrm{OHCca})]$ $(34.10 \mu \mathrm{M})$. Phenanthroline has previously been shown to be a potent anti-fungal agent against $C$. albicans (Coyle et al., 2003). In the this study, the 1,10-phenanthroline was combined with coumarin-silver complex to yield $\left[\mathrm{Ag}(\mathrm{phen})_{2}(\mathrm{hnc})\right]$. This compound was the most potent antifungal agent screened, with an $\mathrm{MIC}_{80}$ of $4.60 \mu \mathrm{M}$ (Table 1).

Aromatic nitration and hydroxylation of coumarin lead to the production of derivatives with improved anti-fungal activity. This is particularly true in the case of $[\mathrm{Ag}(6-$ OHCca)], which had an $\mathrm{MIC}_{80}$ value of $34.1 \mu \mathrm{M}$. Therefore, oxygenation particularly at the sixth position with a carboxylic group at third position leads to the production of the most active silver-coumarin derivative. However, when this coumarin derivative was complexed with phenanthroline to form $\left[\operatorname{Ag}(\mathrm{phen})_{2}(\mathrm{hnc})\right]$, the $\mathrm{MIC}_{80}$ value was seen to decrease further from a value of $332 \mu \mathrm{M}$ to $4.6 \mu \mathrm{M}$ (Table 1).

\subsection{Effect of coumarin derivatives on cellular respiration}

Previous studies have shown that fungal respiration is affected when cells are exposed to metal-based drugs (Coyle et al., 2003; Eshwika et al., 2004; McCann et al., 2004). Therefore, the respiration rate of cells exposed to each of the different coumarin-silver complexes was determined. The results presented in Table 2 clearly demonstrate that cells pre-grown in the presence of coumarin-3-carboxylic acid and the various silver(I)-coumarin complexes show reduced consumption of oxygen. Those coumarin derivatives which caused the greatest decrease in oxygen consumption were $[\mathrm{Ag}(\mathrm{Cca})](48.24 \mu \mathrm{mol}),[\mathrm{Ag}(6-\mathrm{OHCca})]$ $\left(47.61 \mu \mathrm{mol}\right.$ oxygen $/ 10^{8}$ cells) and $\left[\mathrm{Ag}(\mathrm{phen})_{2}(\mathrm{hnc})\right](42.47$ $\mu \mathrm{mol}$ oxygen $/ 10^{8}$ cells). These results clearly indicate that
Table 2

Oxygen consumption by $C$. albicans cells exposed to complexes

\begin{tabular}{lll}
\hline $\begin{array}{l}\text { Compound } \\
\text { no. }\end{array}$ & $\begin{array}{l}\text { Compounds } \\
\text { screened }\end{array}$ & $\begin{array}{l}\text { Consumption of oxygen } \\
(\mu \mathrm{mol}) \pm \mathrm{SEM}\end{array}$ \\
\hline 1 & $\mathrm{CcaH}$ & $75.45 \pm 2.57$ \\
2 & {$[\mathrm{Ag}(\mathrm{Cca})]$} & $48.24 \pm 1.46$ \\
3 & {$[\mathrm{Ag}(8-\mathrm{OHCca})]$} & $62.94 \pm 2.94$ \\
4 & {$[\mathrm{Ag}(7-\mathrm{OHCca})]$} & $56.02 \pm 2.86$ \\
5 & {$[\mathrm{Ag}(6-\mathrm{OH}-\mathrm{Cca})]$} & $47.61 \pm 0.85$ \\
6 & {$[\mathrm{Ag}(\mathrm{hmnc})]$} & $68.32 \pm 1.86$ \\
7 & {$[\mathrm{Ag}(\mathrm{hnc})]$} & $72.59 \pm 1.24$ \\
8 & {$\left[\mathrm{Ag}(\mathrm{phen})_{2}(\mathrm{hnc})\right]$} & $42.47 \pm 1.78$ \\
& $\mathrm{Control}$ & $82.38 \pm 2.21$ \\
\hline
\end{tabular}

Oxygen consumption was measured using a Clark-type oxygen electrode and expressed as $\mu \mathrm{mol}$ oxygen consumed $/ 10^{8}$ cells $/ \mathrm{min}$. All values are the mean of three independent determinations $\pm \mathrm{SE}$. All values were statistically different when compared to the control at $p<0.05$.

cells pre-grown in the presence of the coumarin derivatives, demonstrated a $20-50 \%$ reduction in oxygen consumption, relative to the control (Table 2). Additionally, $[\mathrm{Ag}(6-$ $\mathrm{OHCca})]$ and $\left[\mathrm{Ag}(\mathrm{phen})_{2}(\mathrm{hnc})\right]$ were previously shown to be the most active anti-fungal agents (Table 1), and the results presented here indicate that they have a significant impact on cellular respiration.

6.3. Cytochromes profiles of coumarin-silver complextreated C. albicans cells

Previous work has indicated that impairment of cytochrome synthesis and/or function leads to a reduction in respiration rates in cells following exposure to metal-based drugs (Coyle et al., 2003; Geraghty and Kavanagh, 2003). The cytochrome profile of control cells indicates the presence of cytochromes $\mathrm{aa}_{3}(602 \mathrm{~nm}), \mathrm{b}(564 \mathrm{~nm})$ and c $(550$ $554 \mathrm{~nm}$ ) (Fig. 2a and b). However, cytochrome spectroscopic profiles were altered when cells were exposed to selected silver(I)-coumarin derivatives at concentration equivalent to half their MIC 80 values. In particular, the
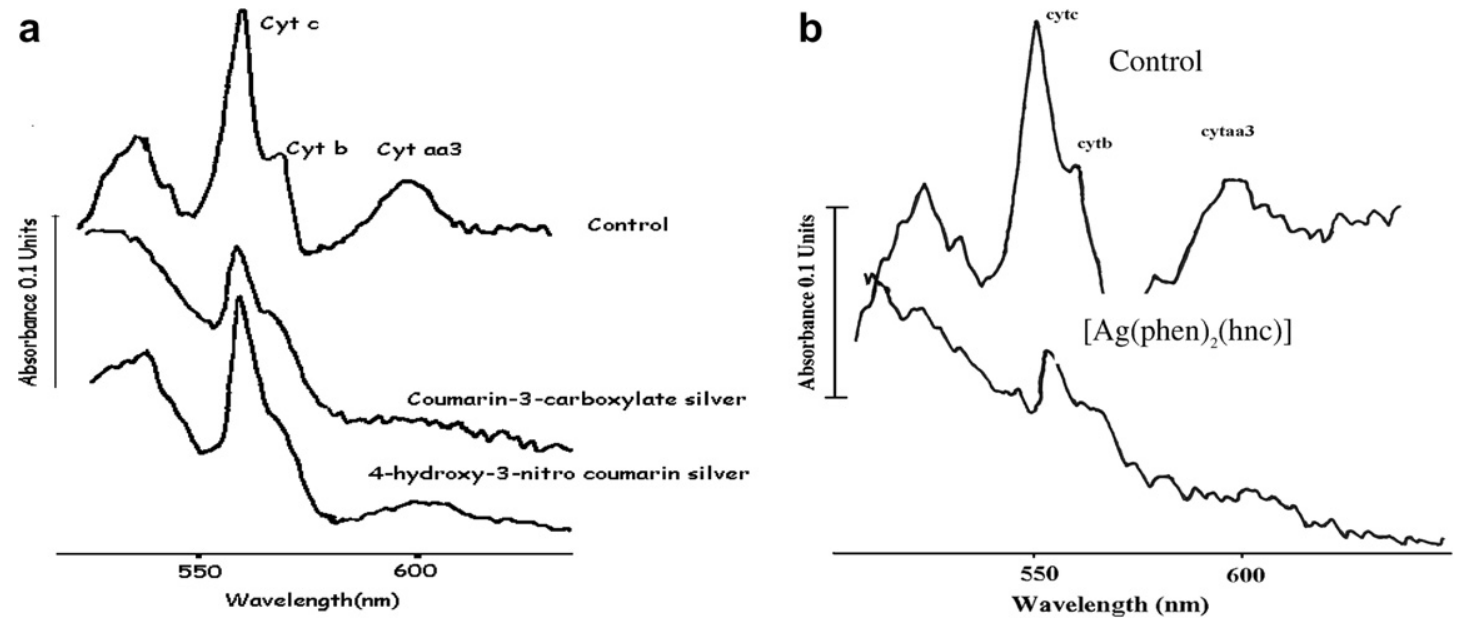

Fig. 2. Cytochrome profile of $C$. albicans following exposure to various silver-coumarin complexes. Fungal cells were treated with coumarin derivatives at concentrations equivalent to half their $\mathrm{MIC}_{80}$ value for $12 \mathrm{~h}$. 
cytochrome $\mathrm{aa}_{3}$ peak was severely disrupted in cultures treated with half $\mathrm{MIC}_{80}$ of both $[\mathrm{Ag}(\mathrm{Cca})]$ and $[\mathrm{Ag}(\mathrm{hnc})]$. The peaks associated with all three cytochromes $\left(\mathrm{aa}_{3}, \mathrm{~b}\right.$, and c) were reduced when cells were treated with $\left[\mathrm{Ag}(\mathrm{phen})_{2}(\mathrm{hnc})\right]$, as shown in Fig. 2b. This result suggests that when silver and phenanthroline were added to coumarin, a reduction in cytochrome synthesis was achieved. However, cytochrome peaks were not disrupted when cells were treated with $[\mathrm{Ag}(\mathrm{hmnc})],[\mathrm{Ag}(8-\mathrm{OHCca})],[\mathrm{Ag}(7-$ $\mathrm{OHCca})]$ and $[\mathrm{Ag}(6-\mathrm{OHCca})]$ (data not shown).

Disruption of the mitochondrial cytochrome content of a cell has the potential to reduce its respiratory efficacy, and this is evident when cells were treated with several of the novel silver-based coumarin derivatives. $[\mathrm{Ag}(\mathrm{Cca})]$ and $[\mathrm{Ag}(\mathrm{hnc})]$ reduced cytochrome $\mathrm{aa}_{3}$, which is an important component of the mitochondrial electron transfer chain. This may have caused respiratory deficiency in C. albicans. $\left[\mathrm{Ag}(\mathrm{phen})_{2}(\mathrm{hnc})\right]$ produced the greatest reduction in all three cytochrome peaks, which may also explain the reduction $(50 \%)$ in oxygen consumption compared to control cells.

\subsection{Determination of ergosterol content of C. albicans cells}

Fungal cells require oxygen in order to synthesise the membrane sterol ergosterol, and so either a reduction in respiratory efficiency or an inability to respire leads to reduced levels of this sterol (Parks and Casey, 1995). Reduction in the ergosterol content in C. albicans has been identified previously as a mechanism for increased growth in the presence of amphotericin B (Kelly et al., 1997; Geraghty and Kavanagh, 2003). The requirement for a functional mitochondrion in ergosterol biosynthesis is well characterised and arises from the provision of NADPH for squalene dimerisation (Parks and Casey, 1995).

In order to elucidate the mechanism of action of the most potent coumarin-silver agents including $\mathrm{CcaH}$, [Ag(Cca)], [Ag(hnc)], [Ag(hmnc)], [Ag(8-OHCca) $],[\mathrm{Ag}(7-$ $\mathrm{OHCca})],[\mathrm{Ag}(6-\mathrm{OHCca})]$ and $\left[\mathrm{Ag}(\mathrm{phen})_{2}(\mathrm{hnc})\right]$, it was decided to investigate their effects on ergosterol synthesis. Concentrations of test agent used here were equivalent to half $\mathrm{MIC}_{80}$ and ergosterol was quantified spectrophotometrically by scanning over the wavelength range of 240 $330 \mathrm{~nm}$ using a dual beam spectrophotometer. Results indicate that treatment with $[\mathrm{Ag}(\mathrm{Cca})],[\mathrm{Ag}(\mathrm{hnc})]$ and [Ag(7-OHCca) $]$ leads to a reduction in ergosterol content (Table 3). Also, the greatest reduction was seen following treatment with $\left[\mathrm{Ag}(\mathrm{phen})_{2}(\mathrm{hnc})\right]$, indicating that this is the most potent of all of the derivatives studied.

\subsection{Assessment of membrane leakage in coumarin-silver complex-treated cells}

Reduced levels of ergosterol can adversely affect membrane integrity and lead to increased membrane permeability. In order to ascertain the effect of depleted ergosterol on membrane integrity, leakage of amino acids across the
Table 3

Ergosterol content of $C$. albicans cells

\begin{tabular}{lll}
\hline $\begin{array}{l}\text { Compound } \\
\text { no. }\end{array}$ & $\begin{array}{l}\text { Compounds } \\
\text { screened }\end{array}$ & $\begin{array}{l}\text { Ergosterol content } \\
(\mu \mathrm{g} / \mathrm{ml}) \pm \mathrm{SEM}\end{array}$ \\
\hline 1 & $\mathrm{CcaH}$ & $45 \pm 2.45$ \\
2 & {$[\mathrm{Ag}(\mathrm{Cca})]$} & $30 \pm 1.58$ \\
3 & {$[\mathrm{Ag}(8-\mathrm{OHCca})]$} & $50 \pm 1.46^{+}$ \\
4 & {$[\mathrm{Ag}(7-\mathrm{OHCca})]$} & $40 \pm 1.53$ \\
5 & {$[\mathrm{Ag}(6-\mathrm{OH}-\mathrm{Cca})]$} & $20 \pm 0.75$ \\
6 & {$[\mathrm{Ag}(\mathrm{hmnc})]$} & $60 \pm 2.24^{+}$ \\
7 & {$[\mathrm{Ag}(\mathrm{hnc})]$} & $32 \pm 1.82$ \\
8 & {$\left[\mathrm{Ag}(\text { phen })_{2}(\mathrm{hnc})\right]$} & $15 \pm 0.75$ \\
& Control & $50 \pm 1.45$ \\
\hline
\end{tabular}

Fungal cells were treated with coumarin derivatives at a concentration equivalent to half their $\mathrm{MIC}_{80}$ value for $12 \mathrm{~h}$. Ergosterol was extracted and quantified according to the method of Arthington-Skaggs et al. (2000). Results are the mean of three independent determinations \pm SE. All values were statistically different when compared to the control (compound 1) at $p<0.05$ except the values for compound 3 and 6 which were not deemed statistically significant.

plasma membrane was measured when cells were exposed to the coumarin compounds for a period of $4 \mathrm{~h}$. The results (Fig. 3) indicate that exposure of stationary phase cells to $[\mathrm{CcaH})]$ lead to the release of $15 \mu \mathrm{g}$ amino acids per $10^{10}$ cells. Exposure of cells to each of the silver-coumarin derivatives significantly increased this leakage, with the greatest seen following incubation with $[\mathrm{Ag}(\mathrm{hnc})]$. These results indicate that the addition of silver to coumarin serves to increase the leakage of amino acids from $C$. albicans, a phenomenon which may be due to the depletion of the ergosterol levels which renders the membrane unstable. Leakage of amino acids together with other small molecular weight compounds from the cell would serve to damage the cell's

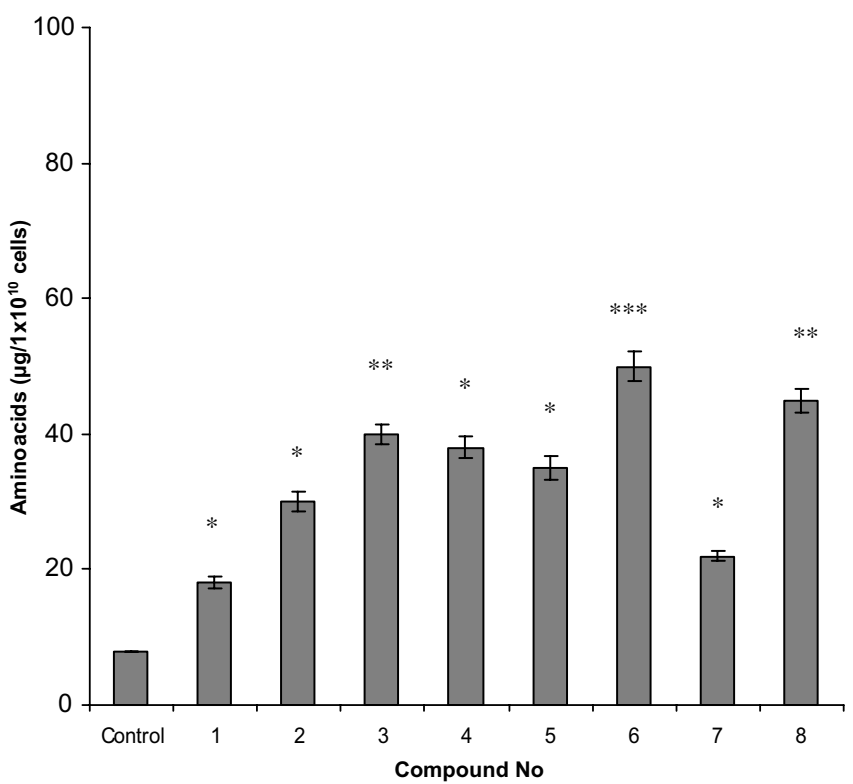

Fig. 3. Amino acids release from C. albicans. Membrane leakage was quantified following treatment of stationary phase cells with test agent for $4 \mathrm{~h}$ and measuring the escape of amino acids as described. Assay was performed on three independent occasions and results are the mean $\pm \mathrm{SE}$. ${ }^{*} p<0.05,{ }^{* *} p<0.01$ and ${ }^{* * *} p<0.005$ with respect to the control. Compound number refer to the complexes listed in Table 1 . 
ability to respire and grow and thus may ultimately contribute to their death.

\subsection{Electronmicrographic analysis of cell morphology}

Exposure of $C$. albicans cells to metal-phenanthroline complexes induces many of the morphological characteristics of apoptosis (programmed cell death) (Coyle et al., 2004; McCann et al., 2004). In particular, there was evidence of ruptured cell walls, withdrawal of the cytoplasm from within the cell wall and the presence of large distended nuclei. In some cases distinct nuclear fragments were also apparent (Coyle et al., 2004). In the work presented here TEM was used to examine the internal morphology of cells grown in the presence of each of the test compounds. Control cells showed normal cellular morphology, including a distinct cell wall, an intact nucleus and numerous membranous organelles (Fig. 4a). In contrast, cells exposed to $\mathrm{CcaH}$ showed evidence of nuclear crescent formation and loss of membranous organelles. In addition, cells exposed to $[\mathrm{Ag}(\mathrm{Cca})]$ or $[\mathrm{Ag}(\mathrm{hnc})]$ also showed evidence of nuclear crescent formation but furthermore demonstrated nuclear fragmentation, features which are consistent with the induction of apoptotic cell death (Fig. 4b-d). In parallel with this analysis DNA was extracted from cells exposed to test agents and separated by agarose gel electrophoresis.

a

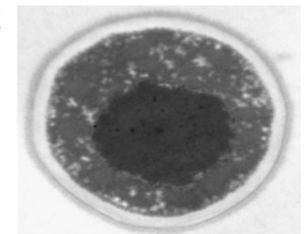

b
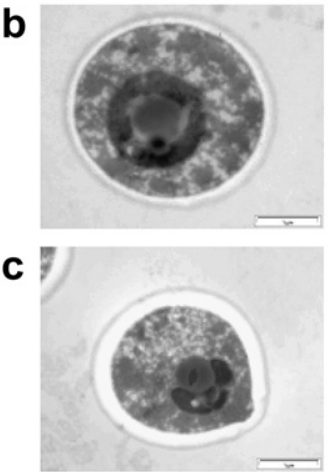

d

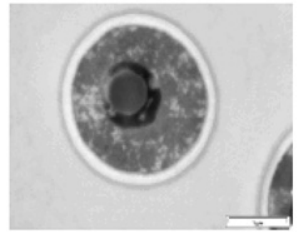

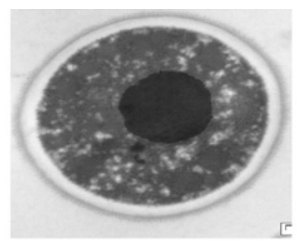
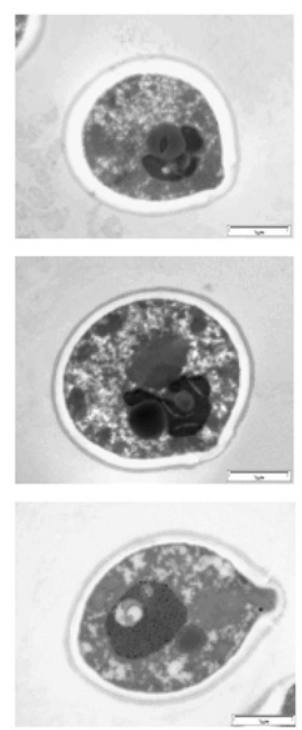

Panel a :

Panel b:

Panel c:

Panel d:
C. albicans: Control.

C. albicans treated with coumarin-3-carboxylic-acid

C. albicans treated with coumarin-3-carboxylate silver

C. albicans treated with 4-Hydroxy-3-nitro-coumarin-silver

Fig. 4. Electronmicrographs of $C$. albicans cells exposed to coumarin and coumarin-silver derivatives.
The results indicate extensive degradation of DNA from those cells exposed to $[\mathrm{Ag}(8-\mathrm{OHCca})],[\mathrm{Ag}(7-\mathrm{OHCca})]$ and [Ag(6-OHCca) $]$ (Fig. 5) - a feature consistent with the apoptotic induced fragmentation of DNA in yeast (Coyle et al., 2004).

\section{Discussion}

The work presented here indicates that while $\mathrm{CcaH}$ and $[\mathrm{Ag}(\mathrm{Cca})]$ demonstrate anti-fungal activity, derivatising these agents with the inclusion of a hydroxy, nitro or phenanthroline ligand, serves to significantly increase their anti-fungal potency. Most of the silver(I)-coumarin derivatives appear to reduce the respiration rate of C. albicans, possibly by disrupting the synthesis of cytochromes in the mitochondrion. Disruption of the mitochondrial cytochrome content of a cell has the potential to reduce its respiratory efficacy, while restoration of respiratory function following transfer of mitochondria by protoplast fusion has the capacity to restore, partially or completely, respiratory status (Ferenczy and Maraz, 1977). In our study, all three cytochromes were reduced by $\left[\operatorname{Ag}(\operatorname{phen})_{2}\right.$ (hnc)] which may explain why this complex caused the greatest diminution in oxygen consumption by $C$. albicans. Reduced respiration has previously been shown to lead to a reduction in the synthesis of ergosterol, a sterol essential for maintaining membrane integrity (Kelly et al., 1997; Geraghty and Kavanagh, 2003). Synthesis of ergosterol is dependent upon a functional mitochondrion to provide NADPH for one of the steps in its biosynthesis. Previous work has demonstrated that cells which have reduced levels of ergosterol are more tolerant of the anti-fungal effects of agents such as amphotericin $\mathrm{B}$ which acts by binding ergosterol and forming pores in the cell membrane (Geraghty and Kavanagh, 2003). Cells treated with the coumarin derivatives demonstrated increased membrane leakage, as evident by the increased leakage of amino acids. A similar effect has been shown previously with the fungus Aspergillus fumiga$t u$ s when treated with either amphotericin B or DMSO. In both cases, increased membrane permeability was observed (Reeves et al., 2004). Additionally, cells exposed to specific silver-coumarin derivatives demonstrated non-specific cleavage of DNA and many of the morphological features of programmed cell death.

The current work demonstrates that the anti-fungal activity of coumarin-silver(I) complexes is mediated by the disruption of respiration which leads to increased membrane leakage due to the depleted synthesis of ergosterol. A further effect is the appearance of morphological features consistent with the induction of the apoptotic death pathway. In mammalian cells, the key event in the induction of apoptosis is loss of cytochrome $\mathrm{c}$ from the mitochondrion which triggers the apoptotic cascade (Green and Kroemer, 1998). It is speculated that the critical event in the anti-fungal activity of the compounds studied here, is the disruption of cytochrome synthesis. This would lead to the inhibition of respiration, reduced ergosterol biosynthesis and the increased membrane 


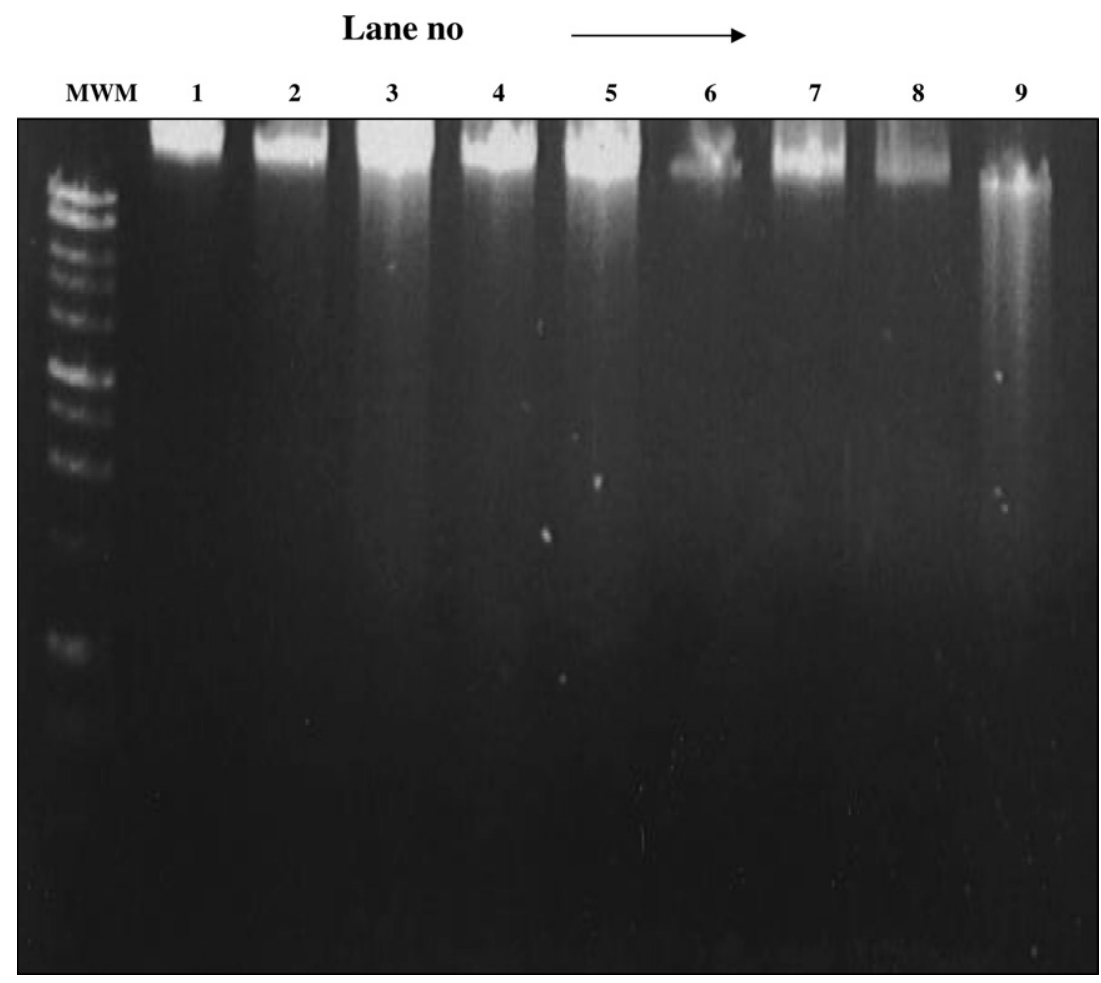

Fig. 5. DNA fragmentation patterns following exposure to various silver-coumarin complexes. Cells were treated with the following coumarin derivatives as described: Lane 1: control cells, 2: [Ag(Cca0], 3: [Ag(8-OHCca)], 4: [Ag(7-OHCca)], 5: [Ag(6-OHCca)], 6: [Ag(hmnc)], 7: [Ag(hnc)], 8: [Ag(phen)2(hnc)] and 9: $\mathrm{AgNO}_{3}$ as the positive control. Molecular weight marker (MWM) were used to indicate the size of the DNA fragments (Promega 10kb marker).

permeability. In addition, loss of cytochrome c (or depletion of its levels within the cell) may trigger an apoptotic response in the cell leading to DNA cleavage and the appearance of features (eg. crescent formation, nuclear fragmentation) consistent with this mode of cell death.

While coumarins have well characterised anti-neoplastic properties (Thornes et al., 1982; Thornes 1983; Ebbinghaus et al., 1997; Finn et al., 2002, 2004, 2005) the results presented here demonstrate that coumarin-3-carboxylic acid and the various silver(I)-coumarin complexes exhibit strong anti-fungal activities which are mediated through the disruption of respiratory function and the induction of apoptosis. In recent years, there has been an increase in the number of fungal isolates manifesting resistance to conventional anti-fungal agents (Kontoyiannis and Lewis, 2002). In light of this, there has been an intensive search for new drugs designed either to circumvent resistance or target alternative cellular targets to the existing range of drugs. While polyene anti-fungals bind ergosterol in the fungal cell membrane and azoles inhibit ergosterol biosynthesis, the compounds described here demonstrate a different mode of action and consequently may have potential applications in the treatment of infections caused by fungi that are resistant to conventional drugs. Due to the problems of drug resistance among pathogenic fungi, it is possible that the agents described here could be employed either alone or in combination with existing agents in order to treat specific infections (Antonella et al., 2003).

\section{Conflict of interest}

The authors have no conflicts of interest to declare.

\section{Acknowledgement}

This research was supported by the Technological Sector Research Programme, Strand III (2002-2005), under the European Social Fund Operational Programme for Industrial Development. The research was carried out by the Pharma Research and Development Team jointly located at Institutes of Technology, Tallaght and Dublin, and the National University of Ireland, Maynooth, Co. Kildare, Ireland.

\section{References}

Antonella, L., Peter, H.N., Mario, C., Mario, D., Romano, D., 2003. Molecular targeted treatments for fungal infections: the role of drug combinations. Trends Mol. Med. 9, 269-276.

Arthington-Skaggs, B.A., David, W.W., Christine, J.M., 2000. Quantitation of C. albicans ergosterol content improves the correlation between in vitro anti-fungal susceptibilty test results and in vivo outcome after fluconazole. Treatment in a murine model of invasive candidosis. Antimicrob. Agent Chemother. 44, 2081-2093.

Coleman, D.C., Rinaldi, M.G., Haynes, K.A., Rex, J.H., Summerbell, R.C., Anaissie, E.J., Sullivan, D.J., 1998. Importance of Candida species other than Candida albicans as opportunistic pathogens. Med. Mycol. 36, 56-65.

Coyle, B., Kavanagh, K., McCann, M., Devereux, M., Geraghty, M., 2003. Mode of anti-fungal activity of 1,10-phenanthroline and its $\mathrm{Cu}(\mathrm{II})$, $\mathrm{Mn}(\mathrm{II})$ and $\mathrm{Ag}(\mathrm{I})$ complexes. Biometals 16, 321-329. 
Coyle, B., Kinsella, P., McCann, M., Devereux, M., O'Connor, R., Clynes, M., Kavanagh, K., 2004. Induction of apoptosis in yeast and mammalian cells by exposure to 1,10-phenanthroline metal complexes. Toxicol. In Vitro 18, 63-70.

Creaven, B.S., Egan, D.A., Kavanagh, K., McCann, M., Mahon, M., Noble, A., Thati, B., Walsh, M., 2005. Synthesis and Antimicrobial Activity of Copper(II) and Silver(I) Complexes of Hydoxy-nitrocoumarins: X-ray crystal structures of $\left[\mathrm{Cu}(\mathrm{hnc})_{2}\left(\mathrm{H}_{2} \mathrm{O}\right)_{2}\right] \cdot 2 \mathrm{H}_{2} \mathrm{O}$ and $[\mathrm{Ag}(\mathrm{hnc})](\mathrm{hncH}=4$ hydroxy-3-nitro-2 $H$-chromen-2-one). Polyhedron 4, 949-956.

Creaven, B.S., Egan, D.A., Kavanagh, K., McCann, M., Noble, A., Thati, B., Walsh, M., 2006. Synthesis, anti-microbial and anti-cancer activity of a series of substituted coumarin-3-carboxylatosilver(I) complexes. Inorg. Chim. Acta 359, 3976-3984.

Ebbinghaus, S.W., Mohler, J.L., Marshall, M.E., 1997. Renal cell carcinoma: the background, rational and current development of coumarin as a potential therapeutic agent. In: Coumarins, Biology, Applications and Mode of action. John Wiley, Chichester, England.

Eshwika, A., Coyle, B., Devereux, M., McCann, M., Kavanagh, K., 2004. Metal-complexes of 1,10-phenanthroline-5,6-dione alter the susceptibility of the yeast Candida albicans to amphotericin B and miconazole. Biometals 17, 415-422.

Ferenczy, L., Maraz, A., 1977. Transfer of mitochondria by protoplast fusion in Saccharomyces cerevisiae. Nature 268, 524-525.

Finn, G., Creaven, B.S., Egan, D., 2002. In vitro cytotoxic potential and mechanism of action of selected coumarins, using human renal cell lines. Cancer Lett. 183, 61-68.

Finn, G., Creaven, B.S., Egan, D., 2004. Daphnetin induced differentiation of human renal carcinoma cells and its mediation by $\mathrm{p} 38$ mitogen-activated protein kinase. Biochem. Pharm. 67, 1779-1788.

Finn, G., Creaven, B.S., Egan, D., 2005. Effects of Coumarin derivatives on differentiation of melanotic melanoma cells: a functional role for mitogen-activated protein kinases. Eur. J. Pharma Sci. 26, 16-25.

Geraghty, P., Kavanagh, K., 2003. Disruption of mitochondrial function in Candida albicans leads to reduced cellular ergosterol levels and elevated growth in the presence of Amphotericin B. Arch Microbiol. 179, 295-300.

Green, D., Kroemer, G., 1998. The central executioners of apoptosis: caspases or mitochondria? Trends Cell Biol. 8, 267-271.

Irena, K., Ilia, M., Irina, N., Spiro, K., Margarita, K., 2001. New lanthanide complexes of 4-methyl-7-hydroxy-coumarin and their pharmacological activity. Eur. J. Med. Chem. 36, 339-347.

Kawase, M., Motohasi, N., Sakagami, H., Kanamato, T., Nakashima, H., Fereczy, L., Walfard, K., Miskolci, C., Molnar, J., 2001. Antimicrobial activity of trifluromethyl ketones and their synergism with promethazine. Int. J. Antimicrob. Agents 18, 161-165.

Kelly, S.I., Lamb, D.C., Kelly, D.E., Manning, N.J., Loeffier, J., Herbart, H., Schumacher, U., Einsele, H., 1997. Resistance to fluconazole and cross-resistance to amphotericin B in Candida albicans from AIDS patients caused by defective sterol $\Delta^{5,6}$ desaturation. FEBS Lett. 400 , $80-82$.

Kontoyiannis, D.P., Lewis, R.E., 2002. Anti-fungal drug resistance in pathogenic fungi. Lancet 359, 1135-1143.

Laurin, P., Klich, M., Dupis-Hamelin, C., Mauvais, P., Lassaigne, P., Bonnefoy, A., Musicki, B., 1999. Synthesis and in vitro evaluation of novel highly potent coumarin inhibitors of gyrase B. Bioorg. Med. Chem. Lett. 9, 2079-2084.

Lewis, R.J., Singh, O.M., Skarzynski, T., Maxwell, A., Wonacott, A.J., 1996. The nature of inhibition of DNA gyrase by the coumarins and the cyclothialidines. EMBO J. 15, 1412-1420.

McCann, M., Coyle, B., McKay, S., McCormack, P., Devereux, M., Kavanagh, K., McKee, V., Kinsella, P., O'Connor, R., Clynes, M., 2004. Synthesis and X-ray crystal structure of $\left[\mathrm{Ag}(\text { phendio })_{2}\right] \mathrm{ClO}_{4}$ (phendio $=$ 1,10-phenanthroline-5,6-dione) and its effects on fungal and mammalian cells. Biometals 17, 635-645.

Micheal, A.P., 1995. Epidemiology of fungal infections: the promise of molecular typing. Clin. Infect Dis. 20, 1535-1539.

Parks, L.W., Casey, W.M., 1995. Physiological implications of sterol biosynthesis in yeast. Ann. Rev. Microbiol. 49, 95-116.

Reeves, E.P., Murphy, T., Daly, P., Kavanagh, K., 2004. Amphotericin B enhances the synthesis and release of the immunosuppressive agent gliotoxin from the pulmonary pathogen Aspergillus fumigatus. J. Med. Microbiol. 53, 719-725.

Thornes, R.D., 1983. Coumarins, melanoma, and cellular immunity. Protect. Agents Cancer, 43-56.

Thornes, R.D., Lynch, G., Sheehan, M.V., 1982. Cimetidine and coumarin therapy of melanoma. Lancet II, 328.

Tiew, P., Ioset, J.R., Kokpal, U., Chavasiri, W., Hostettmam, K., 2003. Anti-fungal, anti-oxidant and larvicidal activities of compounds isolated from the heart wood of Mansonia gagei. Phytotyher. Res. 17, 190193.

Warnock, D., 1998. Fungal infections in neutropenia: current problems and chemotherapeutic control. J. Antimicro. Chemother. 41, 95105.

Zaha, A.A., Hazem, A., 2002. Antimicrobial activity of two novel coumarin derivatives: 3-cyanonaptho[1,2-(e)] pyran-2-one and 3-cyano coumarin. New Microbiol. 25, 213-222. 